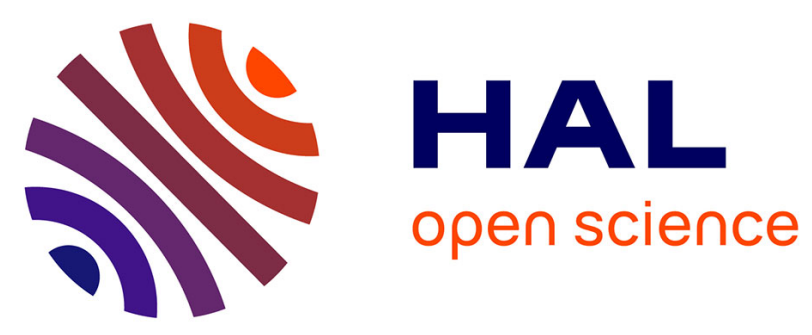

\title{
Reassessment of Cosmodus Sauvage, 1879, a poorly known genus of large pycnodont fish (Actinopterygii, Pycnodontiformes) from the Cenomanian (Upper Cretaceous) of Western Europe
}

Romain Vullo, Jean-Pierre Archambeau, Gilles Bailly, Pierre Bénéfice

\section{To cite this version:}

Romain Vullo, Jean-Pierre Archambeau, Gilles Bailly, Pierre Bénéfice. Reassessment of Cosmodus Sauvage, 1879, a poorly known genus of large pycnodont fish (Actinopterygii, Pycnodontiformes) from the Cenomanian (Upper Cretaceous) of Western Europe. Cretaceous Research, 2018, 91, pp.217-228. 10.1016/j.cretres.2018.05.019 . insu-01819797

\section{HAL Id: insu-01819797 https://hal-insu.archives-ouvertes.fr/insu-01819797}

Submitted on 21 Jun 2018

HAL is a multi-disciplinary open access archive for the deposit and dissemination of scientific research documents, whether they are published or not. The documents may come from teaching and research institutions in France or abroad, or from public or private research centers.
L'archive ouverte pluridisciplinaire HAL, est destinée au dépôt et à la diffusion de documents scientifiques de niveau recherche, publiés ou non, émanant des établissements d'enseignement et de recherche français ou étrangers, des laboratoires publics ou privés. 


\section{Accepted Manuscript}

Reassessment of Cosmodus Sauvage, 1879, a poorly known genus of large pycnodont fish (Actinopterygii, Pycnodontiformes) from the Cenomanian (Upper Cretaceous) of Western Europe

Romain Vullo, Jean-Pierre Archambeau, Gilles Bailly, Pierre Bénéfice

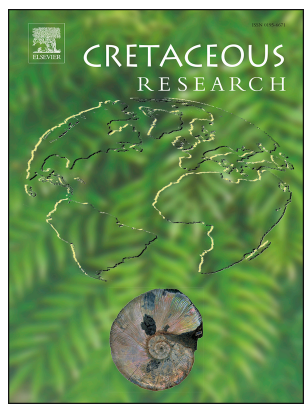

PII:

S0195-6671(18)30109-5

DOI:

10.1016/j.cretres.2018.05.019

Reference: YCRES 3893

To appear in: Cretaceous Research

Received Date: 21 March 2018

Revised Date: 7 May 2018

Accepted Date: 30 May 2018

Please cite this article as: Vullo, R., Archambeau, J.-P., Bailly, G., Bénéfice, P., Reassessment of Cosmodus Sauvage, 1879, a poorly known genus of large pycnodont fish (Actinopterygii, Pycnodontiformes) from the Cenomanian (Upper Cretaceous) of Western Europe, Cretaceous Research (2018), doi: 10.1016/j.cretres.2018.05.019.

This is a PDF file of an unedited manuscript that has been accepted for publication. As a service to our customers we are providing this early version of the manuscript. The manuscript will undergo copyediting, typesetting, and review of the resulting proof before it is published in its final form. Please note that during the production process errors may be discovered which could affect the content, and all legal disclaimers that apply to the journal pertain. 
1 Reassessment of Cosmodus Sauvage, 1879, a poorly known genus of large pycnodont fish

2 (Actinopterygii, Pycnodontiformes) from the Cenomanian (Upper Cretaceous) of

3

4

5

6

7

\section{Western Europe}

Romain Vullo $^{\mathrm{a}, *}$, Jean-Pierre Archambeau ${ }^{\mathrm{b}}$, Gilles Bailly ${ }^{\mathrm{c}}$, Pierre Bénéfice ${ }^{\mathrm{d}}$

${ }^{a}$ Univ Rennes, CNRS, Géosciences Rennes, UMR CNRS 6118, Campus de Beaulieu, 263, avenue du Général Leclerc, F-35000 Rennes, France

${ }^{\mathrm{b}}$ 4, rue Saint-Just, F-17000 La Rochelle, France

${ }^{c}$ Musée d'Angoulême, 1, rue Friedland, F-16000 Angoulême, France

d 23A, rue des Barraudes, La Cotinière, F-17310 Saint-Pierre-d'Oléron, France

* Corresponding author.

Email address: romain.vullo@univ-rennes1.fr (R. Vullo).

Declaration of interest: none.

\section{ABSTRACT}

The large pycnodontiform fish genus Cosmodus Sauvage, 1879 is redescribed on the basis of both historical material and new specimens, and a formal diagnosis is proposed. The vomerine and prearticular dentitions of Cosmodus show a unique combination of characters, including the morphology and ornamentation of the tooth crowns and the number of tooth rows. Cosmodus is thus recognized as a valid distinct genus, restricted to the middle-upper Cenomanian of Western Europe (France, England, Spain, and possibly Germany) and including a single species, C. carentonensis (Coquand, 1859). Cosmodus shares some peculiar 
dental features with Coccodus (e.g., vomerine dentition with three rows of subtriangular teeth) and is therefore tentatively interpreted as a gigantic member of the Coccodontidae, a family of highly specialized pycnodont fishes so far known only from the middle-upper Cenomanian of Lebanon.

Keywords: Actinopterygii; Pycnodontiformes; Coccodontidae; Cosmodus; Dentition; Cenomanian.

\section{Introduction}

The order Pycnodontiformes is a widespread group of ray-finned fishes known from the Upper Triassic to the Eocene (e.g., Martín-Abad and Poyato-Ariza, 2013). Although pycnodontiform genera and species should be preferably defined and diagnosed on the basis of complete, articulated skeletons (Poyato-Ariza and Wenz, 2002), isolated vomerine and prearticular dentitions with unique features (or unique combinations of characters) are still regularly used to erect new taxa (e.g., Poyato-Ariza and Bermúdez-Rochas, 2009; Shimada et al., 2010; Stumpf et al., 2017; Vullo et al., 2017).

The Cenomanian genus Cosmodus, based on isolated dentitions, was erected by Sauvage (1879) to accommodate a large pycnodontiform species that had been previously assigned to the genus Gyrodus (G. carentonensis Coquand, 1859). Subsequently, the genus

Cosmodus has been unanimously regarded as a junior synonym of the widespread genus Coelodus Heckel, 1854 (Woodward, 1895, 1909, 1918; Priem, 1908, 1909, 1912; Kriwet and Schmitz, 2005), although it clearly appears that the former possesses distinctive dentitions with a unique combination of characters. Here, the genus Cosmodus is reassessed and 
redescribed on the basis of material coming from the type region (Charentes, northern Aquitaine Basin, southwestern France) and from other parts of Western Europe (Anglo-Paris Basin and northern Spain). This material is used here to designate a neotype, to provide a formal diagnosis of the type and only species, Cosmodus carentonensis (Coquand, 1859), and to discuss, by comparison with other taxa, the systematic affinities of the genus.

Institutional abbreviations. APVSM, Association Paléontologique de Villers-sur-Mer; MA, Muséum d'Auxerre; MCNA, Museo de Ciencias Naturales de Álava, Vitoria-Gasteiz ; MGM, Museo Geominero, Madrid; MHNLM, Musée Vert, Muséum d'Histoire Naturelle, Le Mans; MHNLR, Muséum d'Histoire Naturelle de La Rochelle; NHMUK, Natural History Museum, London, UK.

\section{Geological settings}

\subsection{Type area}

The lost type specimen (Fig. 1) described by Coquand (1859, 1860a, b) and Sauvage $(1879,1880)$ was collected by the naturalist Alphonse T. de Rochebrune at Pont-de-Basseau in Angoulême, Charente department (northern Aquitaine Basin). In their respective descriptions, Coquand $(1859,1860 \mathrm{a}, \mathrm{b})$ and Sauvage $(1879,1880)$ did not provide any information on the exact stratigraphic position of the specimen within the Cenomanian series, indicating only "étage carentonien" [Carentonian Stage] or "étage à Caprina adversa" [Caprina adversa Stage] (see Francis, 1984). Since 2000, intensive collecting of Cenomanian vertebrates in the surrounding area of Angoulême has allowed to precisely locate the 
stratigraphic position of Cosmodus (Vullo, 2007). It appears that isolated teeth and fragmentary dentitions (MHNLR 2017.10.4) of Cosmodus commonly occur in the marls and clays ("argiles tégulines" of Coquand, 1858) of the lower upper Cenomanian lithological units C4 and D (Calycoceras guerangeri Zone; Moreau, 1996; Néraudeau et al., 1997) outcropping in several clay pits ("Le Pas", "Le Mas" and "L'Amas" quarries) opened in a small area southwest of Angoulême (towns of Nersac, La Couronne and Roullet-Saint-Estèphe) (Vullo, 2007) (Fig. 2). These shallow marine deposits have yielded a rich and diverse fossil assemblage (Moreau, 1996), including abundant oysters (Rhynchostreon suborbiculatum, Rastellum diluvianum, Pycnodonte biauriculata, Ceratostreon flabellatum) (Videt, 2004; Videt and Néraudeau, 2007), rare ammonites (Thomelites cf. lattense; Moreau, 1996), brachyuran crabs (Collins et al., 2013; Van Bakel, 2013), echinoids, and common vertebrate remains (Rage and Néraudeau, 2004; Vullo, 2007; Vullo et al., 2007; Vullo and Néraudeau, 2009).

In the Charente-Maritime department, about 100 km west of Angoulême, the île Madame cliffs expose the beds of the lower upper Cenomanian lithological units C4 and D (Calycoceras guerangeri Zone) at the place called "Le Puits des Insurgés" (Fig. 2). The fossil assemblage recovered from these shallow transgressive marine deposits is roughly similar to that found in the Angoulême area. However, oysters are less abundant, ammonites are represented by Pseudocalycoceras sp. and plant fragments (conifers) are present (Videt and Néraudeau, 2007). Besides numerous isolated teeth, complete dentitions of Cosmodus (MHNLR 2017.10.1, MHNLR 2017.10.2, MHNLR 2017.10.3) have been collected at "Le Puits des Insurgés". In the île Madame Cenomanian series, a few teeth of Cosmodus have been also found in the underlying marly limestone deposits of the middle Cenomanian subunit $\mathrm{C} 2$ and in the overlying sandy oyster bed located at the base of the upper Cenomanian unit E (Fig. 2). 


\subsection{Other localities}

103

104

105

106

107

108

109

110

111

112

113

114

115

Outside the type area (Charentes region), three additional French Cosmodus specimens are known from the Cenomanian of the Paris Basin. They all correspond to historical specimens that were collected with more or less precise stratigraphic data. The first specimen (unnumbered specimen from the APVSM collection), probably found by Charles Bacheley at the end of the $18^{\text {th }}$ century (Brignon, 2016: 599) and subsequently communicated by Auguste Le Prévost to Antoine Passy at the beginning of the $19^{\text {th }}$ century, comes from the lower part of the côte Sainte-Catherine in Rouen (Seine-Maritime department, Normandy) (Passy, 1832). This famous locality, which has provided many fossils since the end of the $18^{\text {th }}$ century, exposes chalky deposits of middle to late Cenomanian age corresponding to the "Craie de Rouen" Formation (Lasseur et al., 2009; Lasseur, 2015). It is very likely that this specimen was collected from the middle Cenomanian phosphatic "Horizon de Rouen" (Acanthoceras rhotomagense Zone), although it might also have been found in one of the overlying strata of the Acanthoceras jukesbrownei Zone. The second specimen (MA 70-530) comes from the middle-upper Cenomanian glauconitic chalk (“Craie glauconieuse”) of Seignelay (Yonne department, Burgundy) (Sauvage, 1879). The third specimen (MHNLM 2013.0.2.21) comes from Coulaines near Le Mans (Sarthe department, Maine), a classic fossil-rich locality which was exposing the middle Cenomanian Jalais sandstone and hardground, at the top of the "Sables et grès du Mans" (Acanthoceras jukesbrownei Zone) (Morel, 2015; Vullo, 2015). Geographic and stratigraphic information about the previously published specimens from England and Spain is provided by Friedman et al. (2016) and Vullo et al. (2009), respectively. The specimen from Halling (Kent, southeastern England), which is the type of Coelodus fimbriatus Woodward, 1893 (NHMUK PV OR 43090), comes from the Holaster 
subglobosus Zone (Lower Chalk, Grey Chalk Group; middle part of the Zig Zag Chalk

Formation; upper middle to lower upper Cenomanian) according to Friedman et al. (2016).

Specimen MGM-2504C from Tiroco (Asturias, northern Spain) comes from the La Cabaña

Formation, which is middle?-late Cenomanian in age. Interestingly, MGM-2504C was found in association with the ammonite Neolobites vibrayeanus (Almela and Ríos, 1962). This ammonite is the index species of a zone partially equivalent to the lower upper Cenomanian Calycoceras guerangeri Zone (Barroso-Barcenilla et al., 2009). In Asturias, some jaw fragments and isolated teeth of Cosmodus have also been collected from coeval beds of the La Cabaña and El Toral quarries near Oviedo (Vullo et al., 2009). An additional, previously unpublished specimen (MCNA registration number pending) comes from the upper Cenomanian of Sóbron (Álava, Basque Country, northern Spain). The geological setting of this area and the Sóbron section are described in detail in Floquet et al. (1996).

\section{Systematic palaeontology}

Osteichthyes Huxley, 1880

Actinopterygii Cope, 1887

Neopterygii Regan, 1923

Pycnodontiformes Berg, 1937

?Coccodontidae Berg, 1940

Cosmodus Sauvage, 1879

Type and only species. Gyrodus carentonensis Coquand, 1859. 
151 Diagnosis. Large-sized pycnodont fish genus that differs from all other pycnodont genera in

152

153

154

155

156

157

158

159

160

161

162

163

164

165

166

167

168

169

170

171

172

173

174

175 having the following combination of characters: elongated, narrow vomerine dentition with three rows of seven or eight subtriangular teeth; teeth of the medial row of the vomer slightly smaller than corresponding adjacent lateral teeth; robust prearticular bone bearing three rows (one main row located medially and two secondary rows located laterally) of large curved drop-shaped teeth (main row) and smaller suboval to subrectangular teeth (secondary rows); complex tooth ornamentation, with a sculpted crown surface (central depression present in all teeth except teeth of the prearticular main row) showing a rugose texture and irregular wrinkles arranged in a more or less pronounced radiating pattern.

Cosmodus carentonensis (Coquand, 1859)

Figs. 1, 3-5A

1832 "Palais de poisson”, “Appareil dentaire de poisson”; Passy, p. 179, pl. 15, fig. 1. ?1856 Gyrodus Münsteri Agassiz; Fischer, p. 138, fig. 21. 1859 Gyrodus carentonensis Coquand: p. 953.

1860a Gyrodus carentonensis Coquand; Coquand, p. 41.

1860b Gyrodus carentonensis Coquand; Coquand, p. 97.

1879 Cosmodus carentonensis (Coquand); Sauvage, p. 49.

1879 Cosmodus grandis Sauvage: p. 49, pl. 3, fig. 29.

1880 Cosmodus carentonensis (Coquand); Sauvage, p. 459, pl. 14, fig. 1.

1893 Coelodus fimbriatus Woodward: p. 491, pl. 17, fig. 6.

1895 Coelodus carentonensis (Coquand); Woodward, p. 257.

1895 Coelodus major Woodward: p. 257.

1908 Coelodus major Woodward; Priem, p. 48. 
1909 Coelodus carentonensis (Coquand); Priem, p. 325.

1909 Coelodus fimbriatus Woodward; Woodward, p. 166, fig. 47.

1912 Coelodus (Gyrodus) carentonensis (Coquand); Priem, p. 269.

1962 Pycnodus sp.; Almela and Ríos, p. 61, pl. 7, fig. 2.

1972 Coelodus fimbriatus Woodward; Benedetto and Sánchez, p. 61, pl. 2, fig. 7.

1997 Gyrodus carentonensis Coquand; Schultz and Paunović, p. 125.

1997 Coelodus fimbriatus Woodward; Schultz and Paunović, p. 102, 127.

2005 Gyrodus carentonensis Coquand; Kriwet and Schmitz, p. 53.

2005 Cosmodus grandis Sauvage; Kriwet and Schmitz, p. 53.

2007 “Coelodus carentonensis" (Coquand); Vullo, p. 79, text-fig. 3.1, pl. 4, fig. 2.

2009 "Cosmodus carentonensis" (Coquand); Vullo et al., p. 122, figs. 2e, 4a.

2015 Coelodus fimbriatus Woodward; Brignon, p. 57, fig. 32.1.

2015 Cosmodus cf. grandis (Sauvage); Vullo, p. 241, fig. 172h.

2016 “Coelodus" fimbriatus Woodward; Friedman et al., p. 171, table 1.

Neotype. MHNLR 2017.10.1, a complete vomerine dentition from "Le Puits des Insurgés", île Madame, Charente-Maritime department, France (Fig. 3A, B).

Paraneotype. MHNLR 2017.10.2, a complete left prearticular dentition from "Le Puits des Insurgés", île Madame, Charente-Maritime department, France (Fig. 3F-H).

Referred material. MHNLR 2017.10.4, a fragmentary vomerine dentition from Nersac ("Le Pas" quarry), Charente department, France (Fig. 3C-E); MHNLR 2017.10.3, a complete right prearticular dentition (juvenile) from "Le Puits des Insurgés", île Madame, CharenteMaritime department, France (Fig. 3I); MA 70-530 (type specimen of Cosmodus grandis Sauvage, 1879), a subcomplete left prearticular dentition from Seignelay, Yonne department, France (Fig. 4A); NHMUK PV OR 43090 (type specimen of Coelodus fimbriatus Woodward, 
1893), a fragmentary right prearticular dentition from Halling, Kent, England (Fig. 4B);

MHNLM 2013.0.2.21, a subcomplete left prearticular dentition from Coulaines, Sarthe department, France (Fig. 4C); APVSM unnumbered specimen, a subcomplete right prearticular dentition from Rouen, Seine-Maritime department, France (Fig. 4D); MGM2504C, a subcomplete right prearticular dentition from Tiroco, Asturias, Spain (Fig. 4E); MCNA (registration number pending), a fragmentary right prearticular dentition from Sóbron, Álava, Spain (Fig. 4F); MHNLR 2017.10.5, a left dentary (or left premaxilla?) from Nersac (“Le Pas" quarry), Charente department, France (Fig. 3J, K).

Type locality and horizon. "Le Puits des Insurgés”, île Madame, Port-des-Barques, Charente-Maritime department, France. Lower upper Cenomanian lithological units C4 and D (Calycoceras guerangeri Zone), “Argiles tégulines de Coquand” Formation (Moreau, 1996;

Néraudeau et al., 1997; Andrieu et al., 2015).

Diagnosis. Same as for genus.

\subsection{Description}

The vomer is an elongate, relatively narrow bone. MHNLR 2017.10.1 (Fig. 3A, B) is a complete vomerine dentition (65 $\mathrm{mm}$ in length) showing 21 teeth closely arranged in three well-defined longitudinal rows. Seven teeth are preserved in each row. The posteriormost tooth of the medial row is missing. In cross-sectional view, the three rows are in the same plane. With the exception of the anterior teeth of the medial row with a diamond-shaped contour, all the teeth show a subtriangular contour in occlusal view. The teeth of the medial row alternate with those of the lateral rows. The teeth have a central depression, which is larger and more rugose and wrinkled in the crowns of the lateral rows. The ornamentation shows a more or less pronounced radiating pattern. The teeth of the medial row show a thick 
transverse bulge posterior to the central depression. MHNLR 2017.10.4 (Fig. 3C-E) is a vomer fragment bearing four teeth. The preserved portion corresponds to the posterior part of the vomer. It shows the second posteriormost tooth of the medial row, and the three posteriormost teeth of the left lateral row. In left lateral view, the bone shows a welldeveloped subvertical oral border above the tooth row. In dorsal view, the bulged lateral margin of the lateral teeth can be seen.

The prearticular corresponds to a massive, well-ossified bone. MHNLR 2017.10.2 (Fig. 3F-H) is a large, complete left prearticular with a well-preserved dentition showing three tooth rows. The main row has nine curved drop-shaped teeth that are devoid of central depression. The largest teeth are $20 \mathrm{~mm}$ in width. Nine and eight teeth are preserved in the inner and outer lateral rows, respectively. However, there were originally ten teeth in each of the two lateral rows, as indicated by empty tooth spaces. The lateral row teeth show a suboval to subrectangular contour and display an ornamentation similar to that of vomerine teeth (i.e., central depression, rugose texture and irregular wrinkles showing a more or less pronounced radiating pattern). The symphysis is thin and long. There is a relatively narrow edentulous area between the main tooth row and the symphysis, corresponding to a medioventral lamina. In cross-sectional view, this lamina is rather thin and concave dorsally. The coronoid process is thick, rather low, and shows a slightly convex dorsal margin. The ventrolateral surface of the prearticular shows a salient coronoid ridge. A large foramen is present laterally, just below the third anterior tooth of the outer lateral row. MHNLR 2017.10.3 (Fig. 3I) is a complete right prearticular belonging to a juvenile. Six teeth are preserved in the main row. The tooth arrangement and tooth morphology are rather similar to those observed in larger specimens, indicating that ontogenetic heterodonty in Cosmodus was very weak. The two main differences with adult dentitions are 1) the proportionally larger size of posterior teeth of 
lateral rows and 2) the higher angle between medial and lateral margins of the dentition. In addition, anterior teeth of the two lateral rows are fused in MHNLR 2017.10.3.

MHNLR 2017.10.5 (Fig. 3J, K) is a small subtriangular, flattened bone bearing two incisiform prehensile teeth. This element, interpreted as a left dentary (or, alternatively, a right premaxilla), is tentatively assigned to Cosmodus because of the presence of unusual ornamentation on the tooth crowns. Both teeth are wider than high and not strongly compressed labiolingually. The lingual faces are irregularly wrinkled and show a basal bulge, whereas the labial faces are smooth.

All the Cosmodus specimens previously described from the Anglo-Paris Basin (Passy, 1832; Sauvage, 1879; Woodward, 1893; Vullo, 2015) and northern Spain (Almela and Ríos, 1962; Vullo et al., 2009) correspond to large prearticular dentitions (Fig. 4A-E). They are less complete than MHNLR 2017.10.2, all lacking the anterior portion of the dentition. However, they clearly show the same tooth arrangement and morphological features that the material from Charentes, displaying a main row with drop-shaped teeth and two secondary rows with smaller suboval to subrectangular teeth ornamented by irregular radiating wrinkles. The new Spanish specimen from Sóbron is a smaller fragment corresponding to the anterior portion of a right prearticular dentition (Fig. 4F). It is also morphologically consistent with the Charentes material.

\section{Discussion}

\subsection{Synonymy and designation of a neotype}

In his synopsis of the Cretaceous fossils of southwestern France ("Synopsis des animaux et des végétaux fossiles observés dans la formation crétacée du sud-ouest de la 
France"), Coquand (1859) provided a brief description without illustration of a new species of pycnodont fish, Gyrodus carentonensis, from the upper Cenomanian of the Angoulême area, Charente department. Coquand's original description of Gyrodus carentonensis was based on a single fragmentary vomer (now lost) bearing six teeth characterized by a peculiar, complex ornamentation (Fig. 1). Later, Sauvage $(1879,1880)$ figured this specimen (Fig. 1), discussed the affinities of this species, found that it was clearly distinct from the other species of Gyrodus, and finally concluded that it should be assigned to a new genus. Thus, Sauvage (1879) erected the genus Cosmodus, in which he also placed a new species, Cosmodus grandis, from the Cenomanian of Seignelay, Yonne department, northeastern France (Fig. 4A). Sauvage $(1879,1880)$ also placed the species Pycnodus imitator Cornuel, 1877 and Pycnodus sculptus Cornuel, 1877 (Lower Cretaceous of Wassy, Haute-Marne department, northeastern France; Cornuel, 1877, 1880) in his new genus Cosmodus, but these two species must be assigned to the genus Gyrodus (Woodward, 1895). The type specimens of Gyrodus imitator and Gyrodus sculptus are prearticular dentitions which display the same features that those of Gyrodus sp. described from the Lower Cretaceous of Germany (Kriwet and Schmitz, 2005). Because neither Gyrodus imitator nor Gyrodus sculptus displays diagnostic features, these two species must be considered as nomina dubia and the type material is here referred to Gyrodus sp.

Woodward (1893) described a new large species of Coelodus, C. fimbriatus, on the basis of an incomplete prearticular dentition from the Lower Chalk of Halling, Kent, southeastern England (Fig. 4B). The dental morphology and tooth arrangement of this prearticular dentition clearly indicate that this species belongs to the genus Cosmodus. Both Cosmodus grandis Sauvage, 1879 and Cosmodus fimbriatus (Woodward, 1893) are undistinguishable from the type species (known by several vomerine and prearticular dentitions), and these two taxa are therefore regarded here as junior synonyms of Cosmodus 
carentonensis (Coquand, 1859). In the present study, we select the complete vomerine dentition MHNLR 2017.10.1 from the "Argiles tégulines de Coquand" Formation of the Charentes region (type horizon and area) as the neotype of Cosmodus carentonensis, consistently with the type specimen originally described by Coquand (1859). In addition, the complete prearticular dentition MHNLR 2017.10.2, collected from the same locality that yielded the neotype (i.e., "Le Puits des Insurgés", île Madame), is designated as paraneotype. A prearticular dentition from the middle-upper Cenomanian of the côte SainteCatherine in Rouen (Normandy, northwestern France), originally figured by Passy (1832: pl. 15, fig. 1) as "appareil dentaire de poisson" [dental apparatus of fish] and recently referred to Coelodus fimbriatus by Brignon (2015), can be confidently assigned to Cosmodus carentonensis (Fig. 4D).

\subsection{Comparisons and affinities}

The genus Cosmodus shares some dental features with a few other pycnodont genera. Several authors have considered the genus Cosmodus as a subjective junior synonym of the genus Coelodus (Woodward, 1895, 1909, 1918; Priem, 1908, 1909, 1912; Kriwet and Schmitz, 2005). Woodward (1895: 257) even proposed the replacement name Coelodus major for Coelodus grandis (Sauvage, 1879), which consequently became a junior homonym of Coelodus grandis (Costa, 1856). Like Cosmodus, Coelodus typically has three prearticular tooth rows (Woodward, 1909; Schultz and Paunović, 1997; Poyato-Ariza and Wenz, 2002; Szabó et al., 2016). However, Cosmodus clearly differs from Coelodus by the tooth shape, the tooth ornamentation, and the number of vomerine tooth rows (Woodward, 1909; Schultz and Paunović, 1997; Poyato-Ariza and Wenz, 2002) (Table 1). As in Cosmodus, the prearticular of the genus Anomoeodus also shows a main tooth row with comma-shaped crowns. 
However, the vomerine and prearticular dentitions of Anomoeodus display more tooth rows than those of Cosmodus. In addition, the teeth of Anomoeodus are generally smooth or less ornamented than those of Cosmodus (Kriwet, 1999, 2002; Poyato-Ariza and Wenz, 2002;

Friedman, 2012) (Table 1). As Cosmodus, the much smaller coccodontid (sensu lato) genera Coccodus and Ichthyoceros also have a vomer bearing three rows of subtriangular teeth (Poyato-Ariza and Wenz, 2002: fig. 22d; Fig. 5B). However, the prearticular dentition of Coccodus shows only two tooth rows (Poyato-Ariza and Wenz, 2002; Kriwet, 2005: fig. 44) (Table 1). In Ichthyoceros, there are three prearticular tooth rows as in Cosmodus, but the two secondary rows are located medially and laterally to the main row (Poyato-Ariza and Wenz, 2002: fig. 23a). The presence of three tooth rows in both the vomerine and prearticular dentitions is known in several other pycnodontiform taxa (e.g., Arcodonichthys, Paramicrodon, Phacodus, Proscinetes, Neoproscinetes), but the teeth of the main vomerine tooth row are never triangular in contour and are always larger and wider that those of lateral rows (Thurmond, 1974; Hooks et al., 1999; Poyato-Ariza et al., 1999; Poyato-Ariza and Wenz, 2002; Poyato-Ariza and Bermúdez-Rochas, 2009). Lastly, it is worth noting that a rugose tooth crown ornamentation rather similar to that of Cosmodus is convergently present in the large Eocene species Pycnodus mokattamensis, an otherwise distinct pycnodont with five vomerine tooth rows and suboval teeth (Priem, 1897, 1899). The new material described here confirms the validity of the genus Cosmodus, which can be clearly distinguished from Coelodus and other pycnodontiforms by its unique combination of characters.

As Cosmodus is known only by isolated dentitions, caution is needed when attempting to determine the systematic affinities of this genus. However, unusual dental features of Cosmodus provide clues regarding its familial assignment. Interestingly, Poyato-Ariza and Wenz (2002) found that subtriangular vomerine teeth represent an autapomorphic character of the clade Coccodus + Ichthyoceros within the Coccodontidae (sensu lato), a highly 
specialized family of small-sized, well-armored pycnodonts so far restricted to the middleupper Cenomanian of Lebanon (Poyato-Ariza and Wenz, 2002; Martín-Abad and PoyatoAriza, 2013; Taverne and Capasso, 2014). In addition, Cosmodus shares with Coccodus a suite of characters, including the number and relative width of vomerine tooth rows (three rows of subequal widths), the slenderness of the vomer (high length/width ratio), the tooth crown ornamentation (e.g., vomerine teeth with wrinkled central depression and peripheral bulges), the morphology of main prearticular teeth (curved drop-shaped contour), and the number of teeth in main rows of vomerine and prearticular dentitions (less than 10) (PoyatoAriza and Wenz, 2002; Kriwet, 2005; Taverne and Capasso, 2014) (Fig. 5). As far it is known, Cosmodus mainly differs from Coccodus by its much larger size, its more marked tooth crown ornamentation, and the presence of an additional lateral tooth row in the prearticular dentition. In conclusion, dental features of Cosmodus indicate that this genus is more closely related to Coccodus than to any other pycnodontiform genus, and Cosmodus is therefore tentatively referred to the Coccodontidae.

\subsection{Distribution and palaeoecology}

Outside the Aquitaine Basin, where the type area is located (Coquand, 1859; Sauvage, 1880; Vullo, 2007), the genus Cosmodus is known from the Anglo-Paris Basin (Passy, 1832; Sauvage, 1879; Woodward, 1893; Vullo, 2015) and from the Asturian Central Depression in the northern margin of the Iberian Peninsula (Almela and Ríos, 1962; Vullo et al., 2009) (Fig. 6). An additional Spanish occurrence is reported here, based on a previously unpublished specimen coming from the upper Cenomanian of Sóbron (Álava, Basque Country) in the Basque-Cantabrian Basin (Fig. 6). Lastly, a single tooth from the upper Cenomanian (Metoicoceras geslinianum Zone; Dölzschen Formation) of Plauen (Saxony, eastern 
Germany), originally described as "Gyrodus Münsteri”, shows a suboval contour, a central depression and short radiating wrinkles (Fischer, 1856; Licht and Kogan, 2011). This specimen, about $6 \mathrm{~mm}$ in largest diameter and likely corresponding to an anterior tooth of a prearticular lateral row, may be referred to Cosmodus. However, this assignment, based on Fischer's original figure (Fischer, 1856: fig. 21), must be considered as highly tentative. Cosmodus therefore appears to be well distributed in Western Europe, from chalky facies with boreal influences (as observed in Kent, Seine-Maritime and Yonne; e.g., Lasseur et al., 2009) to more detrital facies with Tethyan influences (as observed in Charentes, Sarthe, Basque Country and Asturias; e.g., Moreau, 1996) (Fig. 6). This indicates that Cosmodus probably lived in a wide range of habitats, from shallow marine to deeper outer shelf environments. However, the material from Charentes, which is abundant, well-preserved and comes from both juvenile and adult individuals, suggests that Cosmodus preferentially inhabited shallow coastal areas such as lagoons and bays. In the type area, Cosmodus cooccurs with other medium-sized to large-sized pycnodont taxa, such as Coelodus, Anomoeodus, Phacodus, and cf. Neoproscinetes (Coquand, 1859, 1860a, b; R. Vullo, pers. obs.). However, the latter are somewhat smaller and Cosmodus corresponds to the largest form of the Charentes pycnodont assemblage, as also observed in the Anglo-Paris Basin and Asturias (Vullo et al., 2009; Vullo, 2015; Friedman et al., 2016). Mid-Cretaceous pycnodont fishes include some particularly large forms, as exemplified by Coelodus ellipticus and Coelodus gyrodoides from the Albian of southern England (Egerton, 1877). With an estimated maximum standard length of about $80 \mathrm{~cm}$ (according to the correlation existing between prearticular length and standard length; see Licht, 2009) and an inferred total length of around one meter, the putative coccodontid Cosmodus carentonensis is one of these largesized pycnodonts that flourished during the mid-Cretaceous and strongly contrasts with the small-sized Lebanese coccodontid taxa (around $10 \mathrm{~cm}$ in total length for Coccodus; Taverne 

and Capasso, 2014). The observed distribution of Cosmodus in Western Europe can be partly correlated with the middle-late Cenomanian development of oysters such as the gryphaeid species Pycnodonte biauriculata (Pycnodonte Event; Dhondt, 1984; Videt, 2004; Wilmsen and Voigt, 2006). These abundant, robust bivalves may have represented a major food resource for such powerful-jawed fishes with a grinding dentition.

If correct, the familial assignment of Cosmodus proposed here considerably extends the palaeogeographic range of the Coccodontidae, a group so far considered endemic to Lebanon (Cavin, 2008; Martín-Abad and Poyato-Ariza, 2013; Taverne and Capasso, 2014; Marramà et al., 2016). The presence of a single coccodontid species in Europe would contrast with the relatively high diversity of Lebanese coccodontids (sensu lato), usually regarded as the result of a local radiation event due to peculiar ecological conditions (Cavin, 2008; Marramà et al., 2016). In addition, this would support the hypothesis that collecting and taphonomic biases (i.e., "Lagerstätten effect") may be responsible for the so far observed geographic restriction of this peculiar lineage to the Middle East, as previously suggested by Marramà et al. (2016). Lebanese coccodontids (sensu lato) mostly come from the lower upper Cenomanian strata of Hâqel and Hjoûla (Taverne and Capasso, 2014). The late Cenomanian age of these two fossil-Lagerstätten was first proposed on the basis of an assemblage of planktonic foraminifera from contiguous deposits (Hemleben, 1977) and subsequently confirmed by the occurrence of the ammonite Allocrioceras cf. annulatum, a species occurring in the Metoicoceras geslinianum Zone (Wippich and Lehmann, 2004). Coccodontids are also present in the En Nammoûra locality (Taverne and Capasso, 2014), which is late middle Cenomanian in age as indicated by associations of benthic foraminifera (Dalla Vecchia et al., 2002). Cosmodus is known from the middle to the upper Cenomanian, occurring from the Acanthoceras jukesbrownei Zone (or possibly the underlying Acanthoceras rhotomagense Zone) to the Calycoceras guerangeri Zone (or possibly the 
overlying Metoicoceras geslinianum Zone). Therefore, Cosmodus shows a restricted stratigraphic distribution that is roughly consistent with that of Lebanese coccodontids. During the latest Cenomanian, Cosmodus apparently became extinct and several equivalent-sized taxa appeared in Europe, North America and Africa during the Turonian. These taxa include some particularly large species of the widespread pycnodontid genus Coelodus (e.g., Woodward, 1909; Priem, 1898; Schultz and Paunović, 1997), the poorly known pycnodontid genus Acrotemnus (= Macropycnodon) (e.g., Woodward, 1909; Shimada et al., 2010; Vullo and Courville, 2014), and the bizarre serrasalmimid genus Polygyrodus (Vullo et al., 2017). It can be assumed that this trend to gigantism in various distinct lineages (reported here for the first time within the Coccodontidae), with some forms exceeding one meter in total length, is one aspect of the explosive early Late Cretaceous diversification observed in pycnodont fishes (Marramà et al., 2016). As early as the Cenomanian, new morphological innovations with obvious defensive functions (e.g., horns, spines, armor) evolved independently in several marine fish lineages (e.g., pycnodonts, acanthomorphs), probably in response to the increased levels of predation characterizing the Mesozoic Marine Revolution (Chen et al., 2014; Marramà et al., 2016). On the basis of the available material (i.e., isolated dentitions), it is not possible to know whether Cosmodus was a well-armored form like small-sized, spinous coccodontids from Lebanon (Taverne and Capasso, 2014). Nevertheless, it is worth noting that the remarkably large size of some mid-Cretaceous pycnodonts such as Cosmodus may have represented an alternative or additional physical defensive adaptation in ecosystems with increasing predation rates.

\section{Conclusions}


Our study shows that the pycnodont fish Cosmodus, occurring in the mid-Cretaceous

450 (Cenomanian) of Western Europe and previously thought to be a junior synonym of

451

452

453

454

455

456

457

Coelodus, is actually a monospecific genus that can be clearly distinguished from all other

taxa. The tooth arrangement and tooth morphology of Cosmodus suggest that this large-sized genus is closely related to Coccodus, a small armored form endemic to Lebanon. Cosmodus is therefore tentatively assigned to the Coccodontidae, a highly specialized family of pycnodonts known so far only from the famous Lagerstätten of Lebanon. This new taxonomic interpretation of Cosmodus would extend the palaeogeographic distribution of coccodontids to the European archipelago. Interestingly, the stratigraphic range of Cosmodus is equivalent to that of Lebanese coccodontids (middle-upper Cenomanian).

Cosmodus, as well as other large mid-Cretaceous pycnodonts (i.e., Coelodus, Acrotemnus, Polygyrodus), probably fed on robust hard-shelled organisms and may have been preyed upon by large top predators such as lamniform sharks and marine reptiles. The gigantism observed in these pycnodont taxa can be interpreted as a direct consequence of an important phase of predator-prey escalation in Cretaceous marine ecosystems (Walker and Brett, 2002).

Our results confirm the important contribution of diagnostic isolated dentitions to our knowledge of the palaeodiversity, palaeobiogeography and palaeoecology of pycnodontiform fishes (e.g., Kriwet and Schmitz, 2005; Kriwet, 2008; Szabó et al., 2016; Stumpf et al., 2017).

\section{Acknowledgments}

We thank Arnaud Brignon for providing information concerning the whereabouts of the Rouen specimen. We are grateful to Horst Gödicke, Jean-Marie Guégan, Bernard Pierson (Association Paléontologique de Villers-sur-Mer), Damien Gendry (Université de Rennes 1), 
Gaëlle Labonne (Muséum d'Auxerre), Nicolas Morel (Musée Vert, Le Mans), Kevin Webb

(Natural History Museum, London), José J. Moratalla and María José Torres (Instituto Geológico y Minero de España, Madrid) for photographs of some specimens, to Didier Néraudeau (Université de Rennes 1) for providing specimen MHNLR 2017.10.3, and to Enrique Bernárdez (Universidad de Atacama, Copiapó) for providing information about the material from Asturias. Access to the Tiroco specimen was kindly provided at the Museo Geominero (IGME, Madrid). Ramiro López Medrano (Ponferrada) is warmly thanked for providing photographs of the specimen from Sóbron and for kindly donating it to the Museo de Ciencias Naturales de Álava. Finally, we wish to thank Giuseppe Marramà and Márton Szabó for their thorough reviews and constructive comments.

\section{References}

Almela, A., Ríos, J.M., 1962. Investigación del Hullero bajo los terrenos mesozoicos de la Costa Cantábrica (zona de Oviedo-Gijón-Villaviciosa-Infiesto). Empresa Nacional “ADARO” de Investigaciones Mineras, Madrid, 171 p.

Andrieu, S., Brigaud, B., Rabourg, T., Noret, A., 2015. The Mid-Cenomanian Event in shallow marine environments: Influence on carbonate producers and depositional sequences (northern Aquitaine Basin, France). Cretaceous Research 56, 587-607.

Barroso-Barcenilla, F., Goy, A., Segura, M., 2009. Ammonite zonation of the upper Cenomanian and lower Turonian in the Iberian Trough, Spain. Newsletters on Stratigraphy 43, 139-164.

Benedetto, J.L., Sánchez, T.M., 1972. Coelodus toncoensis nov. sp. (Pisces, Holostei, Pycnodontiformes) de la Formación Yacoraite (Cretácico superior) de la Provincia de Salta. Ameghiniana 9, 59-71. 
Berg, L.S., 1937. A classification of fish-like vertebrates. Bulletin de l'Académie des Sciences de l'URSS, Classe des Sciences mathématiques et naturelles (série biologique) 4, 1277-1280.

Berg, L.S., 1940. Classification of fishes, both recent and fossil. Travaux de l'Institut Zoologique de l'Académie des Sciences de l'URSS 5, 87-517.

Brignon, A., 2015. Les débuts de la paléontologie en Normandie et dans le Boulonnais. Fossiles 21, 43-62.

Brignon, A., 2016. L’abbé Bachelay et la découverte des premiers dinosaures et crocodiliens marins dans le Jurassique des Vaches Noires (Callovien/Oxfordien, Normandie). Comptes Rendus Palevol 15, 595-605.

Cavin, L., 2008. Palaeobiogeography of Cretaceous bony fishes (Actinistia, Dipnoi and Actinopterygii). In: Cavin, L., Longbottom, A., Richter, M. (Eds.), Fishes and the Break-up of Pangea. Geological Society, London, Special Publications, 295, 165-183.

Chen, W.-J., Santini, F., Carnevale, G., Chen, J.-N., Liu, S.-H., Lavoué, S., Mayden, R.L., 2014. New insights on early evolution of spiny-rayed fishes (Teleostei: Acanthomorpha). Frontiers in Marine Science 1:53.

Collins, J.S.H., Villier, L., Breton, G., 2013. A new etyid crab (Crustacea, Decapoda) from the Cenomanian of France. Bulletin of the Mizunami Fossil Museum 39, 47-49.

Cope, E.D., 1887. Zittel's Manual of Palaeontology. American Naturalist 21, 1014-1019.

Coquand, H., 1858. Description physique, géologique, paléontologique et minéralogique du département de la Charente - Tome premier. Dodivert et $\mathrm{C}^{\mathrm{e}}$, Besançon, $542 \mathrm{p}$.

Coquand, H., 1859. Synopsis des animaux et des végétaux fossiles observés dans la formation crétacée du sud-ouest de la France. Bulletin de la Société géologique de France, $2^{\text {ème }}$ série $16,945-1023$. 
Coquand, H., 1860a. Synopsis des animaux et des végétaux fossiles observés dans les formations secondaires de la Charente, de la Charente-Inférieure et de la Dordogne. Barlatier-Feissat et Demonchy, Marseille, 146 p.

Coquand, H., 1860b. Description physique, géologique, paléontologique et minéralogique du département de la Charente - Tome deuxième. Barlatier-Feissat et Demonchy, Marseille, $420 \mathrm{p}$.

Cornuel, J., 1877. Description de débris de poissons fossiles provenant principalement du calcaire néocomien du département de la Haute-Marne. Bulletin de la Société géologique de France, $3^{\text {ème }}$ série 5, 604-626.

Cornuel, J., 1880. Note sur de nouveaux débris de pycnodontes portlandiens et néocomiens de l'est du bassin de Paris. Bulletin de la Société géologique de France, $3^{\text {ème }}$ série 8,150 162.

Costa, O.G., 1854-1856. Paleontologia del regno di Napoli - Parte II. Cataneo, Napoli, 380 p.

Dalla Vecchia, F.M., Venturini, S., Tentor, M., 2002. The Cenomanian (Late Cretaceous) Konservat-Lagerstätte of en Nammoûra (Kesrouâne Province), northern Lebanon. Bollettino della Società Paleontologica Italiana 41, 51-68.

Dhondt, A.V., 1984. The unusual Cenomanian oyster Pycnodonte biauriculatum. Geobios, Mémoire spécial 8, 53-61.

Egerton, P., 1877. On some new pycnodonts. Geological Magazine, Decade 2, 4, 49-55.

Fischer, C.E., 1856. Die Fischreste aus dem Plänerschichten von Plauen, Strehlen, Weinböhla und Grosssedlitz. Allgemeine deutsche Naturhistorische Zeitung 2, 134-145.

Floquet, M., Mathey, B., Métais, E., Emmanuel, L., Babinot, J.-F., Magniez-Jeannin, F., Tronchetti, G., 1996. Correlation of sedimentary events during the latest Cenomanian from the Basque Basin to the Castilian Ramp (Northern Spain). Geogaceta 20, 50-53. 
Francis, I.H., 1984. Correlation between the North Temperate and Tethyan Realms in the Cenomanian of Western France and the significance of hardground horizons. Cretaceous Research 5, 259-269.

Friedman, M., 2012. Ray-finned fishes (Osteichthyes, Actinopterygii) from the type Maastrichtian, the Netherlands and Belgium. Scripta Geologica Special Issue 8, $113-$ 142.

Friedman, M., Beckett, H.T, Close, R.A., Johanson, Z., 2016. The English Chalk and London Clay: two remarkable British bony fish Lagerstätten. In: Johanson, Z., Barrett, P.M., Richter, M., Smith, M. (Eds.), Arthur Smith Woodward: His Life and Influence on Modern Vertebrate Palaeontology. Geological Society, London, Special Publications 430, 165-200.

Heckel, J., 1854. Über den Bau und die Eintheilung der Pycnodonten, nebst kurzer Beschreibung einiger neuen Arten derselben. Sitzungsberichte der kaiserlichen Akademie der Wissenschaften, Mathematisch-Naturwissenschaftliche Klasse 12, 433464.

Hemleben, C., 1977. Rote Tiden und die oberkretazischen Plattenkalke im Libanon. Neues Jahrbuch für Geologie und Paläontologie, Monatschefte 1977, 239-255.

Hooks, G.E. III, Schwimmer, D.R., Williams, G.D., 1999. Synonymy of the pycnodont Phacodus punctatus Dixon, 1850, and its occurrence in the Late Cretaceous of the southeastern United States. Journal of Vertebrate Paleontology 19, 588-590.

Huxley, T.H., 1880. On the applications of the laws of evolution to the arrangement of the Vertebrata, and more particularly of the Mammalia. Proceedings of the Zoological Society of London 1880, 649-662.

Kriwet, J., 1999. Pycnodont fishes (Neopterygii, $†$ Pycnodontiformes) from the Lower Cretaceous of Uña (E-Spain) with comments on branchial teeth in pycnodontid fishes. 
In: Arratia, G., Schultze, H.-P. (Eds.), Mesozoic Fishes 2 - Systematics and Fossil Record. Verlag Dr. Friedrich Pfeil, München, pp. 215-238.

Kriwet, J., 2002. Anomoeodus pauciseriale n. sp. (Neopterygii, Pycnodontiformes) from the White Chalk Formation (Upper Cretaceous) of Sussex, South England. Paläontologische Zeitschrift 76, 117-123.

Kriwet, J., 2005. A comprehensive study of the skull and dentition of pycnodont fishes. Zitteliana A 45, 135-188.

Kriwet, J., 2008. The dentition of the enigmatic pycnodont fish, Athrodon wittei (Fricke, 1876) (Neopterygii, Pycnodontiformes; Late Jurassic; NW Germany). Fossil Record 11, $61-66$.

Kriwet, J., Schmitz, L., 2005. New insight into the distribution and palaeobiology of the pycnodont fish Gyrodus. Acta Palaeontologica Polonica 50, 49-56.

Lasseur, E., 2015. Stratigraphie et paléogéographie du Cénomanien dans le Bassin parisien. In: Morel, N. (Ed.), Stratotype Cénomanien. Muséum national d'Histoire naturelle, Paris, and Biotope, Mèze, pp. 83-98.

Lasseur, E., Guillocheau, F., Robin, C., Hanot, F., Vaslet, D., Coueffe, R., Néraudeau, D., 2009. A relative water-depth model for the Normandy Chalk (Cenomanian-Middle Coniacian, Paris Basin, France) based on facies patterns of metre-scale cycles. Sedimentary Geology 213, 1-26.

Licht, M., 2009. The relationship of prearticular length and standard length in pycnodontiform fishes. Studia Geologica Salmanticensia 45, 139-148.

Licht, M., Kogan, I., 2011. Late Cretaceous pycnodont fishes (Actinopterygii, Neopterygii) from Saxony (Eastern Germany). Freiberger Forschungshefte, C 540, 79-90.

Marramà, G., Villier, B., Dalla Vecchia, F.M., Carnevale, G., 2016. A new species of Gladiopycnodus (Coccodontoidea, Pycnodontomorpha) from the Cretaceous of 
Lebanon provides new insights about the morphological diversification of pycnodont fishes through time. Cretaceous Research 61, 34-43.

Martín-Abad, H., Poyato-Ariza, F.J., 2013. Historical patterns of distribution in pycnodontiform and amiiform fishes in the context of moving plates. Geologica Belgica $16,217-226$.

Moreau, P., 1996. Analyse de la transgression cénomanienne sur la bordure nord-occidentale du Bassin de l'Aquitaine. Géologie de la France 1, 3-16.

Morel, N., 2015. La stratigraphie du Cénomanien de la Sarthe. In: Morel, N. (Ed.), Stratotype Cénomanien. Muséum national d'Histoire naturelle, Paris, and Biotope, Mèze, pp. 6982.

Néraudeau, D., Thierry, J., Moreau, P., 1997. Variation in echinoid biodiversity during the Cenomanian-early Turonian transgressive episode in Charentes (France). Bulletin de la Société géologique de France 168, 51-61.

Passy, A., 1832. Description géologique du département de la Seine-Inférieure. Nicétas Periaux, Rouen, 371 p.

Philip, J., Floquet, M., Platel, J.-P., Bergerat, F., Sandulescu, M., Bara-Boshkin, E., Amon, E., Guiraud, R., Vaslet, D., Le Nindre, Y., Ziegler, M., Poisson, A., Bouaziz, S., 2000. Late Cenomanian (94.7 to 93.5 Ma). In: Dercourt, J., Gaetani, M, Vrielynck, B., Barrier, E., Biju-Duval, B., Brunet, M.F., Cadet, J.-P., Crasquin, S., Sandulescu, M. (Eds.), Atlas Peri-Tethys, Palaeogeographical Maps. CCGM/CGMW, Paris, map 14.

Poyato-Ariza, F.J., Bermúdez-Rochas, D.D., 2009. New pycnodont fish (Arcodonichthys pasiegae gen. et sp. nov.) from the Early Cretaceous of the Basque-Cantabrian Basin, northern Spain. Journal of Vertebrate Paleontology 29, 271-275.

Poyato-Ariza, F.J., Wenz, S., 2002. A new insight into pycnodontiform fishes. Geodiversitas 24, 139-248. 
Poyato-Ariza, F.J., Fielitz, C., Wenz, S., 1999. Marine actinopterygian fauna from the Upper Cretaceous of Albaina (Laño quarry, northern Spain). Estudios del Museo de Ciencias Naturales de Alava 14 (Núm. Espec. 1), 325-338.

Priem, F., 1897. Sur les poissons de l'Eocène du Mont Mokattam (Egypte). Bulletin de la Société géologique de France, $3^{\text {ème }}$ série $25,212-227$.

Priem, F., 1898. Sur des pycnodontes et des squales du Crétacé supérieur du bassin de Paris (Turonien, Sénonien, Montien inférieur). Bulletin de la Société géologique de France, $3^{\text {ème }}$ série $26,229-243$.

Priem, F., 1899. Sur des poissons fossiles éocènes d'Egypte et de Roumanie et rectification relative à Pseudolates Heberti Gervais sp. Bulletin de la Société géologique de France, $3^{\text {ème }}$ série $27,241-253$.

Priem, F., 1908. Etude des poissons fossiles du Bassin parisien. Publications des Annales de Paléontologie, Masson et $C^{\text {ie }}$, Paris, 144 p.

Priem, F., 1909. Sur un pycnodonte du Sénonien supérieur de Tunisie. Bulletin de la Société géologique de France, $4^{\text {ème }}$ série 9, 324-326.

Priem, F., 1912. Sur des poissons des terrains secondaires du Sud de la France. Bulletin de la Société géologique de France, $4^{\text {ème }}$ série 12, 250-271.

Rage, J.-C., Néraudeau, D., 2004. A new pachyostotic squamate reptile from the Cenomanian of France. Palaeontology 47, 1195-1210.

Regan, C.T., 1923. The skeleton of Lepidosteus, with remarks on the origin and evolution of the lower neopterygian fishes. Proceedings of the Zoological Society of London 1923, $445-461$.

Sauvage, H.-E., 1879. Bulletin de la Société des Sciences historiques et naturelles de l'Yonne, $3^{\text {ème }}$ série $1,20-84$. 
Sauvage, H.-E., 1880. Notes sur les poissons fossiles (suite). Bulletin de la Société géologique de France, $3^{\text {ème }}$ série 8, 451-462.

Schultz, O., Paunović, M., 1997. Der Nachweis von Coelodus (Osteichthyes, Pycnodontidae) im Turonien (Oberkreide) von Gams bei Hieflau, Steiermark, Österreich, und aus der Oberkreide von Kroatien und Italien. Annalen des Naturhistorischen Museums in Wien. Serie A für Mineralogie und Petrographie. Geologie und Paläontologie, Anthropologie und Prähistorie 98, 73-141.

Shimada, K., Williamson, T.E., Sealey, P.L., 2010. A new gigantic pycnodont fish from the Juana Lopez Member of the Upper Cretaceous Mancos Shale of New Mexico, U.S.A. Journal of Vertebrate Paleontology 30, 598-603.

Stumpf, S., Ansorge, J., Pfaff, C., Kriwet, J., 2017. Early Jurassic diversification of pycnodontiform fishes (Actinopterygii, Neopterygii) after the end-Triassic extinction event: Evidence from a new genus and species, Grimmenodon aureum. Journal of Vertebrate Paleontology 37:e1344679.

Szabó, M., Gulyás, P., Ösi, A., 2016. Late Cretaceous (Santonian) pycnodontid (Actinopterygii, Pycnodontidae) remains from the freshwater deposits of the Csehbánya Formation, (Iharkút, Bakony Mountains, Hungary). Annales de Paléontologie 102, $123-$ 134.

Taverne, L., Capasso, L. 2014. Ostéologie et phylogénie des Coccodontidae, une famille remarquable de poissons Pycnodontiformes du Crétacé supérieur marin du Liban, avec la description de deux nouveaux genres. Palaeontos 25, 3-43.

Thurmond, J.T., 1974. Lower vertebrate faunas of the Trinity Division in North-Central Texas. Geoscience and Man 8, 103-129. 
669

670

671

672

673

674

675

676

677

678

679

680

681

682

683

684

685

686

687

688

689

690

691

692

Van Bakel, B.W.M., 2013. Preservation of internal pleurites in a new palaeocorystid crab (Crustacea, Brachyura, Raninoidia) from the Cenomanian (Upper Cretaceous) of Poitou-Charentes, France. Zootaxa 3701, 322-328.

Videt, B., 2004. Dynamique des paléoenvironnements à huîtres du Crétacé supérieur nordaquitains (SO France) et du Moi-Pliocène andalou (SE Espagne) : biodiversité, analyse séquentielle, biogéochimie. Mémoires de Géosciences Rennes 108, 1-261.

Videt, B., Néraudeau, D., 2007. Paléoécologie des ostréidés cénomaniens de la bordure nord du Bassin aquitain (SW France). Bulletin de la Société géologique de France 178, 3950.

Vullo, R., 2007. Les vertébrés du Crétacé supérieur des Charentes (Sud-Ouest de la France) : biodiversité, taphonomie, paléoécologie et paléobiogéographie. Mémoires de Géosciences Rennes 125, 1-302.

Vullo, R., 2015. Les poissons. In: Morel, N. (Ed.), Stratotype Cénomanien. Muséum national d'Histoire naturelle, Paris, and Biotope, Mèze, pp. 237-244.

Vullo, R., Courville, P., 2014. Fish remains (Elasmobranchii, Actinopterygii) from the Late Cretaceous of the Benue Trough, Nigeria. Journal of African Earth Sciences 97, 194 206.

Vullo, R., Néraudeau, D., 2009. Pterosaur remains from the Cenomanian (Late Cretaceous) paralic deposits of Charentes, western France. Journal of Vertebrate Paleontology 29, $277-282$.

Vullo, R., Cappetta, H., Néraudeau, D., 2007. New sharks and rays from the Cenomanian and Turonian of Charentes, France. Acta Palaeontologica Polonica 52, 99-166.

Vullo, R., Bernárdez, E., Buscalioni, A.D., 2009. Vertebrates from the middle?-late Cenomanian La Cabaña Formation (Asturias, northern Spain): Palaeoenvironmental and 
693

694

695

696

697

698

699

700

701

702

703

704

705

706

707

708

709

710

711

712

713

714

715

716

717

palaeobiogeographic implications. Palaeogeography, Palaeoclimatology, Palaeoecology $276,120-129$.

Vullo, R., Cavin, L., Khalloufi, B., Amaghzaz, M., Bardet, N., Jalil, N.-E., Jourani, E., Khaldoune, F., Gheerbrant, E., 2017. A unique Cretaceous-Paleogene lineage of piranha-jawed pycnodont fishes. Scientific Reports 7:6802.

Walker, S.E., Brett, C.E., 2002. Post-Paleozoic patterns in marine predation: Was there a Mesozoic and Cenozoic marine predatory revolution? In: Kowalewski, M., Kelley, P.H. (Eds.), The Fossil Record of Predation. Palaeontological Society Papers 8, 119-193.

Wilmsen, M., Voigt, T., 2006. The middle-upper Cenomanian of Zilly (Sachsen-Anhalt, northern Germany) with remarks on the Pycnodonte Event. Acta Geologica Polonica $56,17-31$.

Wippich, M.G.E., Lehmann, J., 2004. Allocrioceras from the Cenomanian (mid-Cretaceous) of Lebanon and its bearing on the palaeobiological interpretation of heteromorphic ammonites. Palaeontology 47, 1093-1107.

Woodward, A.S., 1893. Some Cretaceous pycnodont fishes. Geological Magazine, Decade 3, 10, 433-436, 487-493.

Woodward, A.S., 1895. Catalogue of Fossil Fishes in the British Museum (Natural History) Part III. Containing the Actinopterygian Teleostomi of the Orders Chondrostei (concluded), Protospondyli, Aetheospondyli, and Isospondyli) (in part). Trustees of the British Museum (Natural History), London, 544 p.

Woodward, A.S., 1909. The fossil fishes of the English Chalk - Part V. Monograph of the Palaeontographical Society, London 63, 153-184.

Woodward, A.S., 1918. The fossil fishes of the English Wealden and Purbeck formations Part II. Monograph of the Palaeontographical Society, London 70, 49-104. 
Figure captions:

720

721

722

Fig. 1. Reproduction of the original drawing of the lost type specimen of Gyrodus carentonensis Coquand, 1859 from the upper Cenomanian of Angoulême (Charente department, northern Aquitaine Basin, France) (after Sauvage, 1880). Scale bar equals $1 \mathrm{~cm}$.

Fig. 2. Map and synthetic section showing the geographic locations and stratigraphic positions (asterisks) of Cosmodus carentonensis (Coquand, 1859) in the type area (Charentes region, northern Aquitaine Basin). Most of the specimens were collected from the lower upper Cenomanian "Argiles tégulines de Coquand" Formation (type horizon).

Fig. 3. Cosmodus carentonensis (Coquand, 1859) from the type region (Charentes, northern Aquitaine Basin, France). A, B, complete vomerine dentition (MHNLR 2017.10.1) from île Madame, Charente-Maritime department, in occlusal view (A) and close-up occlusal view (B) of posteriormost teeth showing the detail of the crown ornamentation. $\mathrm{C}-\mathrm{E}$, fragmentary vomerine dentition (MHNLR 2017.10.4) from Nersac, Charente department, in occlusal (C), dorsal (D) and left lateral (E) views. F-H, complete left prearticular dentition (MHNLR 2017.10.2) from île Madame, Charente-Maritime department, in occlusal (F), ventrolateral (G) and dorsolateral (H) views. I, complete right prearticular dentition of juvenile individual (MHNLR 2017.10.3) from île Madame, Charente-Maritime department, in occlusal view. J, K, left dentary (or right premaxilla?) (MHNLR 2017.10.5) from Nersac, Charente department, in labial (J) and lingual (K) views. Scale bars equal $1 \mathrm{~cm}$. 
Fig. 4. Cosmodus carentonensis (Coquand, 1859) from localities outside the type region. A, subcomplete left prearticular dentition (MA 70-530; type specimen of Cosmodus grandis Sauvage, 1879) from Seignelay, Yonne department, France. B, fragmentary right prearticular dentition (NHMUK PV OR 43090; type specimen of Coelodus fimbriatus Woodward, 1893) from Halling, Kent, England. C, subcomplete left prearticular dentition (MHNLM 2013.0.2.21) from Coulaines, Sarthe department, France. D, subcomplete right prearticular dentition (APVSM unnumbered specimen) from Rouen, Seine-Maritime department, France. E, subcomplete right prearticular dentition (MGM-2504C) from Tiroco, Asturias, Spain. F, fragmentary right prearticular dentition (MCNA registration number pending) from Sóbron, Álava, Spain. All specimen in occlusal view. Scale bar equals $1 \mathrm{~cm}$.

Fig. 5. Comparison between the vomerine dentitions of Cosmodus and Coccodus. A, vomerine dentition of Cosmodus carentonensis (reconstruction based on MHNLR 2017.10.1 and MHNLR 2017.10.4). B, vomerine dentition of Coccodus armatus (reconstruction based on Poyato-Ariza and Wenz, 2002: fig. 22d). Note the subtriangular teeth closely arranged in three rows and the ornamented crowns with a central depression and peripheral bulges. Scale bars equal $1 \mathrm{~cm}(\mathrm{~A})$ and $5 \mathrm{~mm}(\mathrm{~B})$.

Fig. 6. Middle-late Cenomanian palaeogeographic map showing the distribution of Cosmodus carentonensis (red stars) in the epicontinental seas of Western Europe (after Philip et al., 2000). This marine pycnodontiform taxon occurs in Charente-Maritime (1), Charente (2), Sarthe (3), Yonne (4) and Seine-Maritime (5) in France, Kent (6) in England, and Asturias (7) and Álava (8) in Spain; the possible occurrence of Cosmodus in Saxony (eastern Germany) is not taken into account here. 
767 Table 1. Comparison between the dentitions of Cosmodus, Coccodus, Coelodus and

\begin{tabular}{|c|c|c|c|c|}
\hline & $\begin{array}{l}\text { Cosmodus } \\
\text { (this paper) }\end{array}$ & $\begin{array}{l}\text { Coccodus } \\
\text { (after Poyato-Ariza } \\
\text { and Wenz, 2002; } \\
\text { Kriwet, 2005) }\end{array}$ & $\begin{array}{l}\text { Coelodus } \\
\text { (after Poyato-Ariza } \\
\text { and Wenz, 2002) }\end{array}$ & $\begin{array}{l}\text { Anomoeodus } \\
\text { (after Kriwet, 1999, } \\
\text { 2002; Poyato-Ariza } \\
\text { and Wenz, 2002) }\end{array}$ \\
\hline $\begin{array}{l}\text { Morphology of } \\
\text { vomerine teeth }\end{array}$ & $\begin{array}{l}\text { subtriangular } \\
\text { contour }\end{array}$ & $\begin{array}{l}\text { subtriangular } \\
\text { contour }\end{array}$ & suboval contour & $\begin{array}{l}\text { subcircular to } \\
\text { suboval }\end{array}$ \\
\hline $\begin{array}{l}\text { Morphology of } \\
\text { prearticular teeth } \\
\text { (main row) }\end{array}$ & $\begin{array}{l}\text { curved drop-shaped } \\
\text { (comma-shaped) } \\
\text { contour }\end{array}$ & $\begin{array}{l}\text { suboval to curved } \\
\text { drop-shaped } \\
\text { (comma-shaped) } \\
\text { contour }\end{array}$ & $\begin{array}{l}\text { transversally } \\
\text { (mediolaterally) } \\
\text { elongated (capsule- } \\
\text { shaped) contour }\end{array}$ & $\begin{array}{l}\text { sigmoid to curved } \\
\text { drop-shaped } \\
\text { (comma-shaped) } \\
\text { contour }\end{array}$ \\
\hline $\begin{array}{l}\text { Tooth crown } \\
\text { ornamentation }\end{array}$ & $\begin{array}{l}\text { complex, irregular } \\
\text { surface (central } \\
\text { depression, bulges) } \\
\text { with wrinkled and } \\
\text { rugose texture }\end{array}$ & $\begin{array}{l}\text { irregular surface } \\
\text { (transversal groove, } \\
\text { central depression, } \\
\text { bulges); weak } \\
\text { crenulations and } \\
\text { wrinkles } \\
\text { occasionally } \\
\text { present }\end{array}$ & $\begin{array}{l}\text { smooth or } \\
\text { transversal groove }\end{array}$ & $\begin{array}{l}\text { smooth or } \\
\text { transversal groove; } \\
\text { teeth occasionally } \\
\text { mammilated }\end{array}$ \\
\hline $\begin{array}{l}\text { Number of } \\
\text { vomerine tooth } \\
\text { rows }\end{array}$ & three & three & five & five \\
\hline $\begin{array}{l}\text { Number of } \\
\text { prearticular tooth } \\
\text { rows }\end{array}$ & thre & & three & four to eight \\
\hline $\begin{array}{l}\text { Number of teeth } \\
\text { on main tooth row } \\
\text { of vomerine and } \\
\text { prearticular } \\
\text { dentitions }\end{array}$ & less than 10 & less than 10 & 10 or more & $\begin{array}{l}\text { variable (generally } \\
10 \text { or more) }\end{array}$ \\
\hline
\end{tabular}




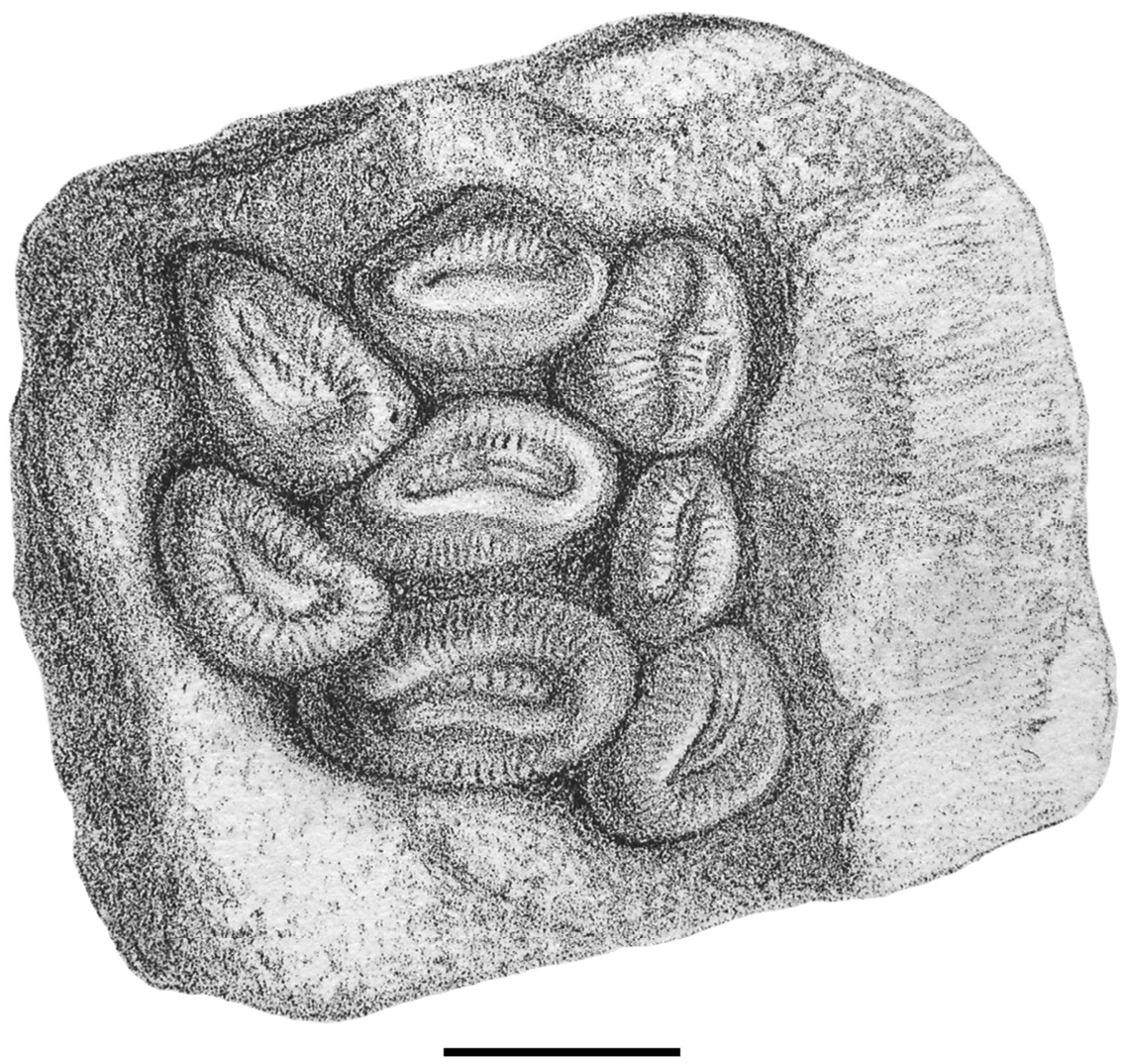




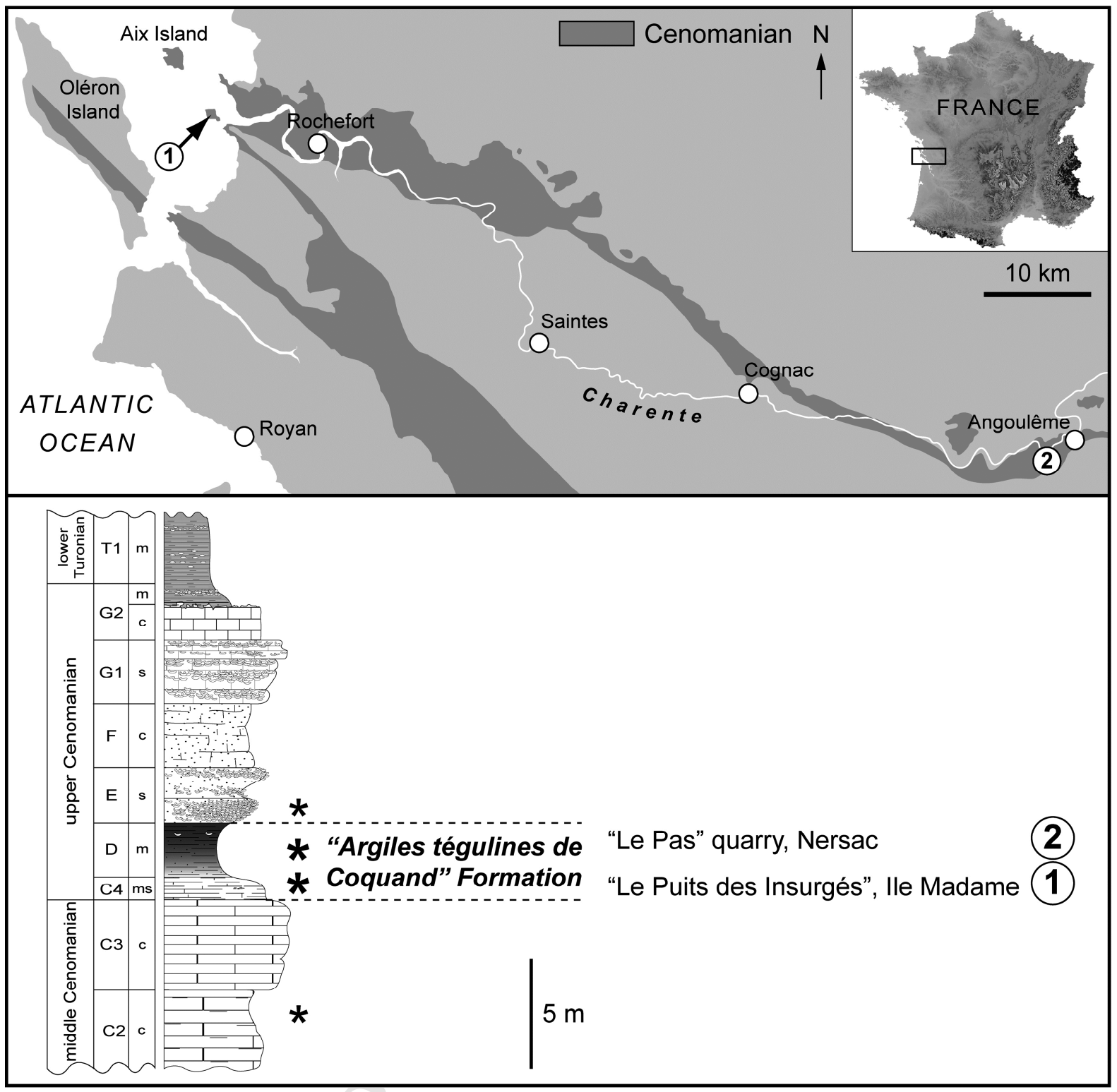



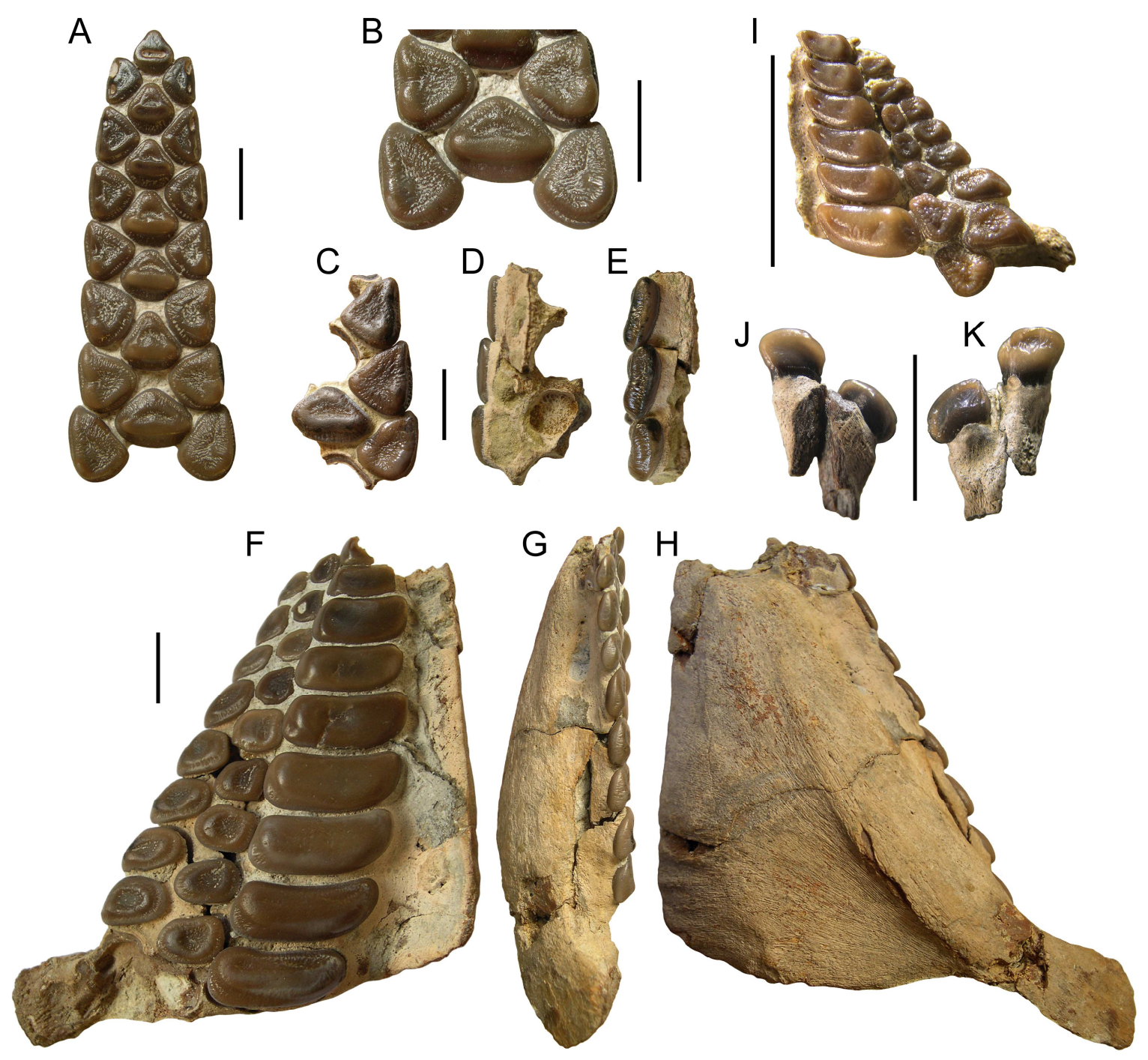
A
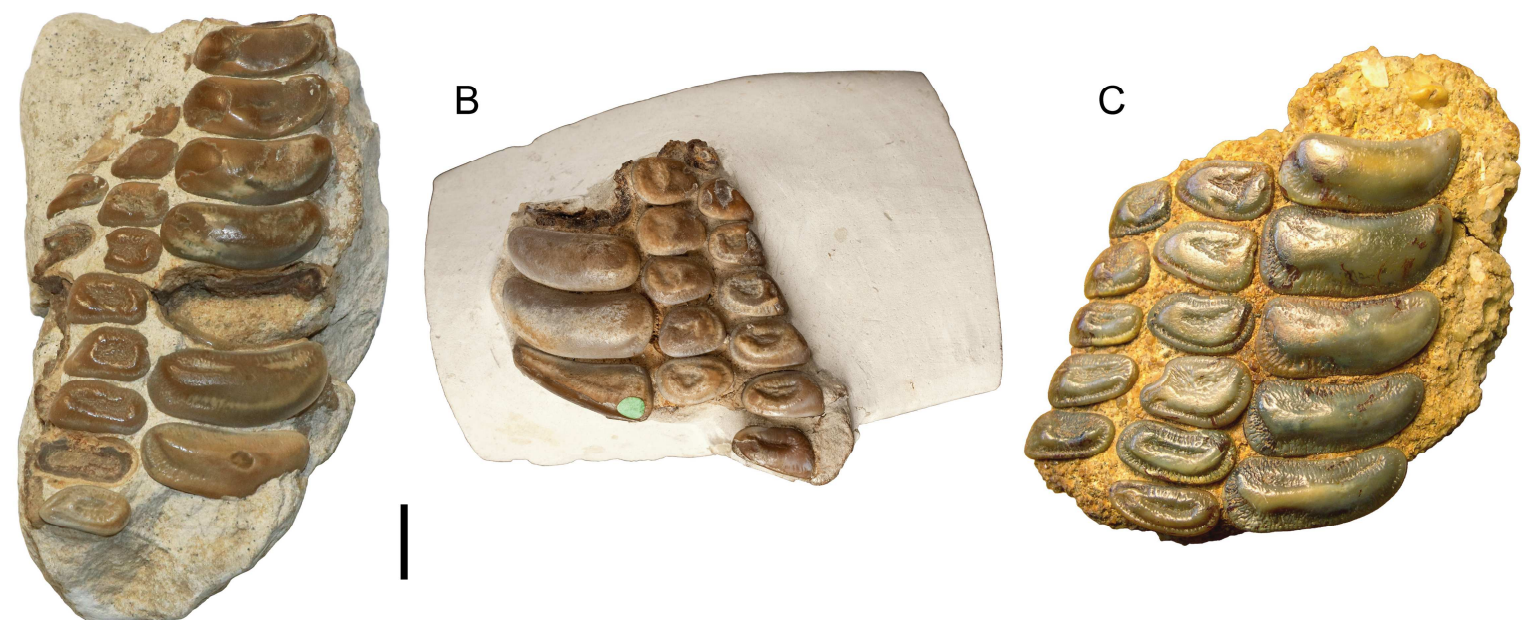

D

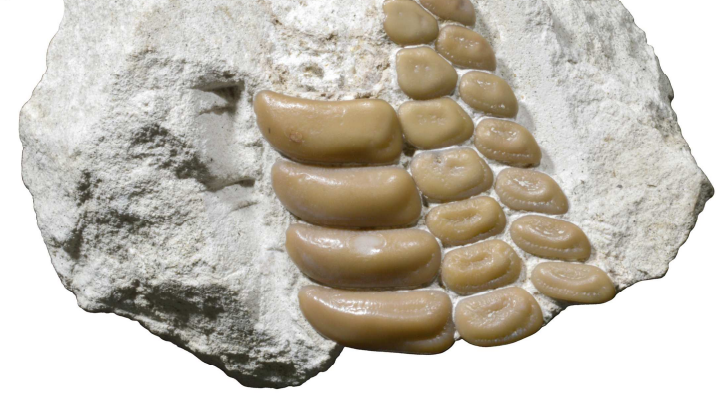

E

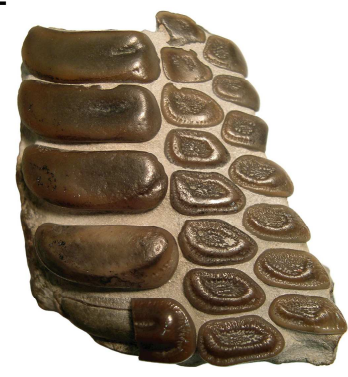

F

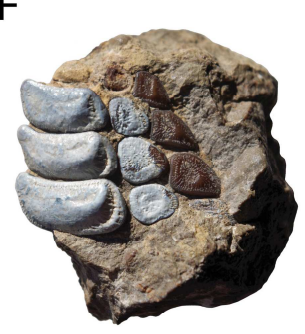


A

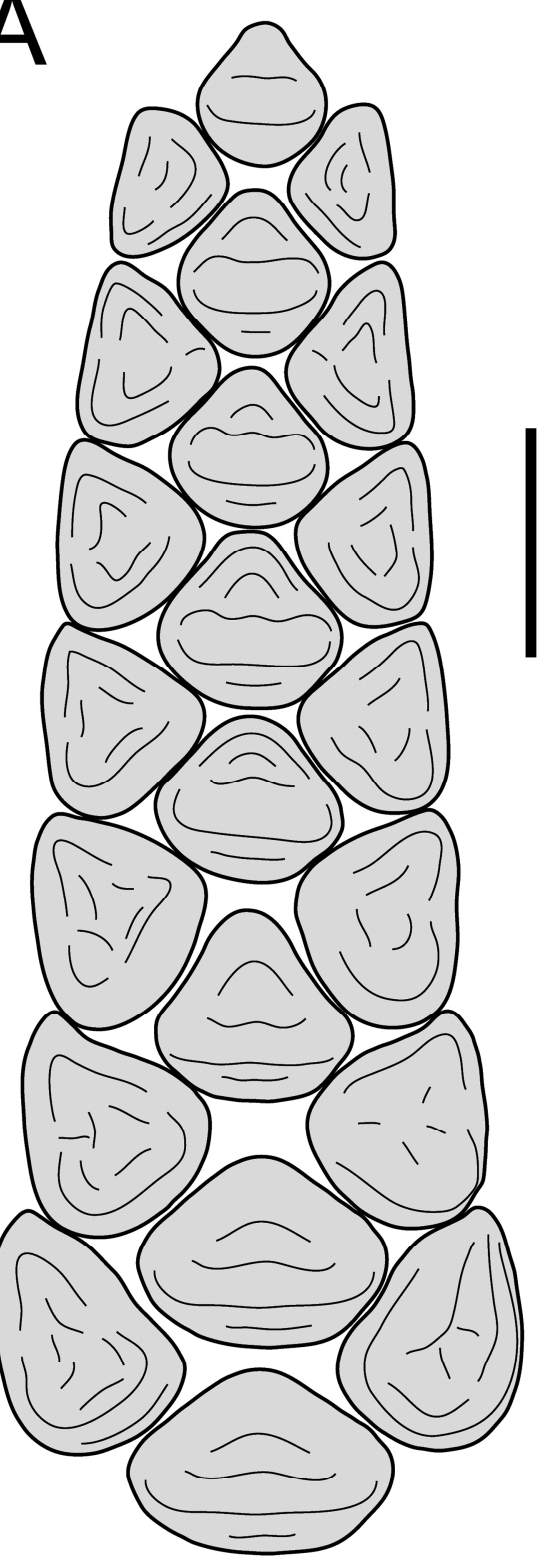

B

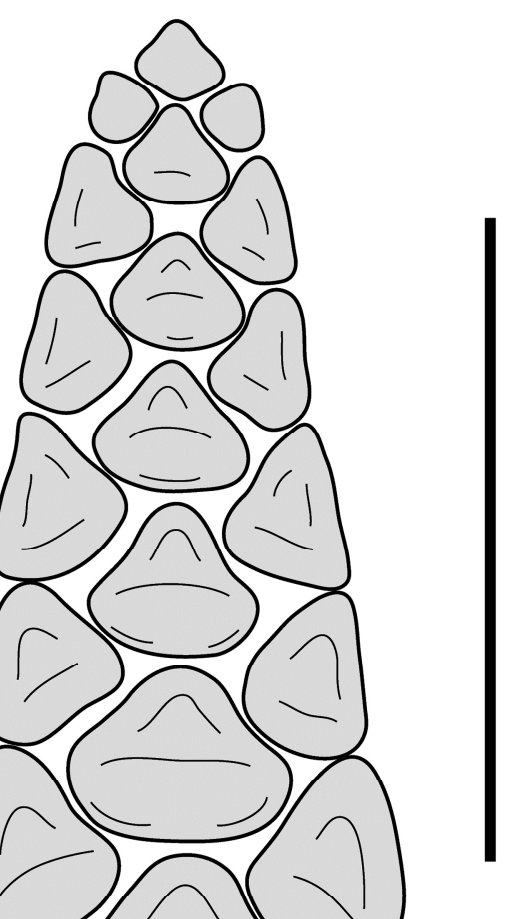




\section{ACCEPTED MANUSCRIPT}

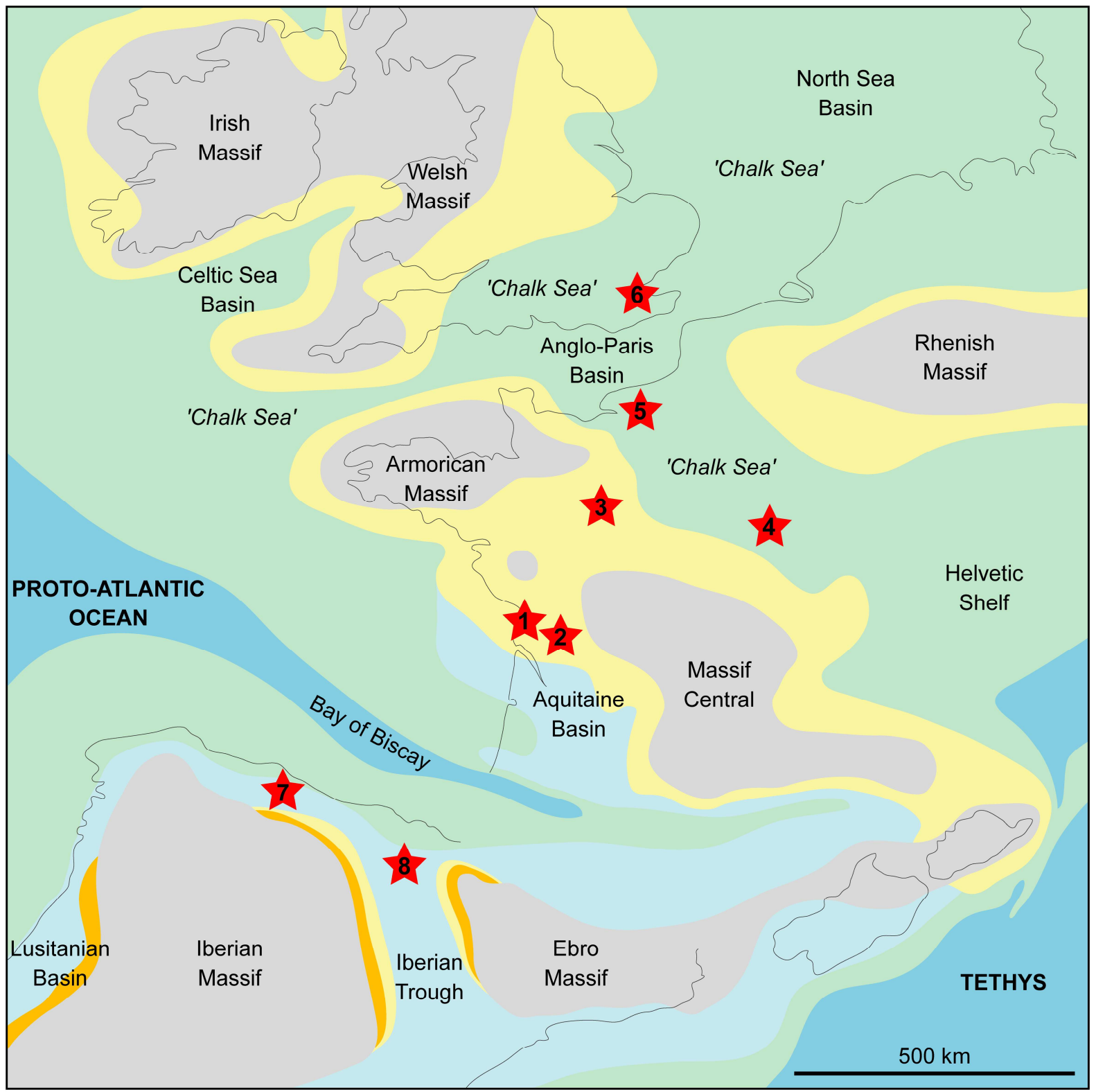

DEPOSITIONAL ENVIRONMENTS

Exposed land

Fluvial, lacustrine

Coastal marine, shallow marine (terrigenous shelves)
Shallow marine carbonates (platforms, build-ups and ramps)

Deep(er) marine carbonates (hemipelagic shelves)

Deep marine 